\title{
Editorial. Foucault and Panopticism Revisited.
}

\section{David Wood 1}

\begin{abstract}
This editorial introduces the issue in the context of the progress of the Surveillance \& Society project. It discusses the theme of this issue, the importance of Michel Foucault's work for Surveillance Studies, briefly summarises the contributions of the authors, and also considers what comes next.
\end{abstract}

\section{Introduction}

This third issue of Surveillance \& Society has been the hardest to produce so far largely because of the sheer quantity and variety of submissions. It reflects what we hope is both our increasing recognition as a serious but innovative project, and our growing transdisciplinary range. As the Managing Editor, I hope you will excuse me if I first use this opportunity to reflect on where the journal is at this time, before moving on to consider the particular theme of the issue.

Approaching the end of our first 'year' of publication, Surveillance \& Society has progressed far beyond the founders' initial expectations. We have had submissions, enquiries and comments from many disciplines (and none) and a large number of different countries. Almost 15,000 people have read at least some of our first two issues. In this issue, there are a variety of disciplinary backgrounds represented (plus a number of particular 'firsts'): geography (Stuart Elden, Hille Koskela); sociology (Sean Hier, Michalis Lianos - whose paper is also our first simultaneous publication in two languages); Criminology (Majid Yar); Communication and Psychology (Paulo Vaz and Fernanda Bruno, also our first contributors from Latin America); Science and Technology Studies (Erich Schienke, whose interview is also accompanied by a short movie, another first for us); Journalism (Mitchell Gray); and finally, from Steve Mann and his multiple collaborators, two innovative and exciting pieces which span a range from computing technology to art.

As an entirely electronic journal, Surveillance \& Society has from the start sought to move beyond the confines of what is possible in a conventional paper journal (and indeed what remains sadly the norm in most electronic academic publications), and has

\footnotetext{
${ }^{1}$ Global Urban Research Unit (GURU), University of Newcastle upon Tyne, UK. mailto:d.f.j.wood@ncl.ac.uk
} 
encouraged the submission of innovative ways of approaching surveillance. We hope that this issue will mark the start of the maturing of that vision. This is not only because of the inclusion of innovative pieces, but also because the publication of this issue also coincides with the launch of the Surveillance \& Society Resource Base, an ongoing and expanding online database of information and materials for Surveillance Studies researchers. As with all our ventures this will need the collaboration and support of our readers to function successfully in the long term. In the long shadow of September $11^{\text {th }}$ 2001 , and the accompanying surge in the application of systems of surveillance and social control that this has provoked (see: Lyon, 2003; Ball and Webster, 2003) now is an extremely important time to be involved with the study of surveillance, and we hope we can continue to contribute to the growth of this transdiscipline.

\section{Foucaultand Panopticism Revisited}

\section{Foucault in Surveilla nce Studies}

When I was talking to colleagues about the theme of this issue, it was put to me that: 'surely every issue of Surveillance \& Society is a Foucault issue'. Michel Foucault (19261984) is often described as the most important philosopher of the second half of the Twentieth Century. For many outside academia he represents the stereotype of the French poststructuralist thinker - prolific and impenetrable. Needless to say, this stereotype is unfair but, in direct contrast, within the humanities and social sciences Foucault has obtained a position of near sainthood; his corpus of work being vital to many disciplines from philosophy to politics to sociology. His own self-description was that of a critical historian of thought. By this he meant not ideas, but the possible knowledges that evolve from the division - and consequent interaction between - subject and object (Foucault, 1984), that which can be called 'modernity'.

For Surveillance Studies, Foucault is a foundational thinker and his work on the development of the modern subject, in particular Surveillir et Punir (translated as Discipline and Punish), remains a touchstone for this nascent transdisciplinary field ${ }^{2}$. This work gave us Foucault's interpretation of Jeremy Bentham's 'Panopticon', an Eighteenth Century design for an ideal reformatory, which will not be dwelt upon here as it has been considered many times before and is present to varying degrees in most of the pieces in this issue. For Foucault the Panopticon represented a key spatial figure in the modern project and also a key dispositif $f^{3}$ in the creation of modern subjectivity, in other words in the remaking of people (and society) in the image of modernity. Panopticism, the social trajectory represented by the figure of the Panopticon, the drive to selfmonitoring through the belief that one is under constant scrutiny, thus becomes both a driving force and a key symbol of the modernist project. Thus it has remained a useful

\footnotetext{
${ }^{2}$ It should not be forgotten that at the same time as Foucault was producing his works on the archaeology of knowledge, American journalists and scholars were producing empirical and critical work on contemporary surveillance practices (in particular: Rule, 1973), and these also form part of the foundations of Surveillance Studies.

${ }^{3}$ A difficult word to translate exactly but which could mean any or all of 'system', 'device' or 'mechanism' etc.
} 
figure as metaphor and comparative for both historical and contemporary developments. And as such - yes, to some extent - every issue of Surveillance \& Society is 'a Foucault issue'.

However, despite this foundational centrality, for the most part Foucault hovers in the background, or gets a cursory, summary and knowing, reference, whether that be positive or otherwise. We all think we know Foucault, and in particular we all think we know what Surveillir et Punir says. This issue attempts to critically consider the contribution of Foucault to Surveillance Studies. The papers included here do this in many different ways, and they have been divided not by 'importance' nor the status neither of the authors, nor - as is our usual practice - by the type of submission, but rather by the general idea theme of their approach. Thus: 'Revisiting Foucault', which contains papers which reassess the general and particular contributions of Foucault to Surveillance Studies; 'The Urban Panopticon', in which authors use Foucault in the context of CCTV surveillance in the contemporary city; 'Resistance / Subversion', which contains pieces which describe and analyse ways of playing with and opposing panoptic trajectories; and finally, 'After Panopticism', which presents two different ways of approaching contemporary social control. Such a categorisation is undoubtedly arbitrary to some extent and there are many overlaps. Rather than performing an in-depth analysis - there is enough depth of thought in the pieces in this issue in themselves - I shall briefly introduce each piece before considering what might come next.

\section{Revisiting Fouc ault}

Majid Ray's piece identifies three main ways in which panopticism is treated by academics: appropriation and application; rejection; and qualified acceptance subject to empirically-dependent limitations. All three tendencies are represented in this issue, though one might also separate out a fourth response to panopticism: critical reinterpretation. For panopticism is both more and less than the functions it has been made to serve by social scientists and critical theorists. Many writers have appropriated the visual-spatial aspects of the Panopticon and ne glected the relationships of this figure with other key elements of Foucault's writing. The paper by Stuart Elden replaces the Panopticon within Foucault's broader concerns with the body, health and disease, and within the archaeology of the institutions of order and control within modern societies, in particular the police. This connects the Foucault of the Panopticon to the Foucault of governmentality and bio-politics, and in this broader reading, the Panopticon is also displaced, becoming less central and more one dispositif amongst many.

Paolo Vaz and Fernanda Bruno also chose to widen the search amongst Foucault's writings on health, concentrating on epidemiological risk and the notion of the subject as self-surveillant. They emphasise that power and care are not easily separable, and indeed that caring surveillance itself seems difficult to analyse in a critical fashion. This goes some way to explaining why - as David Lyon (2001) has previously argued - caring surveillance is unjustly neglected by social researchers in favour of more obvious manifestations of unwelcome and intrusive attention. 


\section{The Urban Panoptic on}

However broadening the view is only one way to reconsider Foucauldian conceptions of surveillance, each of which has greater depth in itself. Hille Koskela argues that even specifically within Foucault's spatial imagining there is a far deeper, more subtle and fluid conception of the spatiality of control, a spatiality which changes, in that beautiful and memorable phrase, 'like a sparkling water'. Mitchell Gray also examines the contemporary urban landscape of control with particular regard to facial recognition systems. However, in contrast to Koskela, rather than concentrating on the spatiality of such systems, he argues that certain technological trajectories, particularly those concerned with reading involuntary 'microexpressions' offer the potential to breach the final domain of privacy, that of thought.

\section{Resistance / Subversion}

In a very exciting piece, Steve Mann, Jason Nolan and Barry Wellman present and analyse various ways in which individuals can use technologies and behaviours to throw the surveillance of authorities and institutions back at them in what they call 'sousveillance'. These practices often occur in an occasional unconscious and sporadic manner, but based on the playful but at the same time serious experiments described, the authors call for a more systematic use of our own powers to produce a 'coveillant' society where the ability to watch is symmetrical. Such playful but serious resistance is also provided by New York's Surveillance Camera Players (also considered by Ray and Koskela in their pieces) who both perform street theatre beneath the gaze, and run tours of surveillance systems in that city (and now others). Erich Schienke's interview with Bill Brown of the SCP explores in more depth the group's history, motivations, activities and the responses of city authorities and ordinary people. The piece is also accompanied by a 15-minute film of an SCP tour. Finally, in this section, Steve Mann reappears with a different group of collaborators, James Fung, Mark Federman and Gianluca Baccanico, with a presentation and description of images from a multi-stranded exhibition, DECONference. The presentation plays with the boundaries of the cyborg (or postcyborg) self, and with notions of contamination and what is sometimes called biosecurity, and in the process throws almost every certainly we have about surveillance into question. It is also very funny.

\section{After Panoptic ism}

Panopticism can, in contrast to reassessments re-emphasising its usefulness described above, be seen as a very specific, historically and culturally contingent tendency. Majid Ray goes on to develop a critique of Foucault that connects his work strongly to Martin Jay's important and controversial thesis that there has been a strong prejudice again the ocular within Twentieth Century French culture. Michalis Lianos, in contrast, makes a strongly argued - and to some no doubt also controversial - case for abandoning the Panopticon as a central metaphor within contemporary surveillance research, and in particular its association with a particular reading of George Orwell's Nineteen EightyFour, arguing that nuanced empirical studies do not support emotive claims to the destruction of privacy and liberty by sinister forces. Instead, in the name of the efficient servicing of consumer demand, society and sociality that has moved beyond the modernist project so accurately described by Foucault, towards a new situation of 
'unintended control', whereby social interactions increasingly operate in socio-technical environments within which negotiation is not possible.

There are of course many other very different 'post-Foucauldian' movements, even within Surveillance Studies, too numerous to recount here. However two of the most exciting strands are those of Foucault's French descendants. Only one of these strands is present amongst the papers here. Sean Hier considers the potential contribution of Deleuze and Guattari. Giles Deleuze is of course known mainly within Surveillance Studies for his short piece, 'A Postscript on the Societies of Control', which remains a key signpost towards the analysis of the transformation of both surveillance, and the subjects of surveillance, being wrought by technologies of digitisation and automation (Deleuze, 1990; see also: Graham and Wood, 2003). However it is only recently that the more general thinking about the structure of socio-technical societies, called by Deleuze and his co-author Felix Guattari, assemblages (Deleuze and Guattari, 1986), has been adapted into Surveillance Studies. This is largely thanks to the seminal article by Haggerty and Ericson, 'The Surveillant Assemblage' (Haggerty and Ericson, 2000). Hier, as he puts it, 'probes' this conceptualisation to tease out its potential implications. He looks at this decentralising, perhaps even democratising, interpretation of surveillance through an examination of welfare regimes, giving us one method by which one might approach caring surveillance in a critical fashion.

\section{What Comes Next}

It is unfortunate that the other major strand of post-Foucauldian social thinking, what has been called 'Actor-Network Theory' (ANT), as developed by Bruno Latour, Michel Callon, John Law and others within Science and Technology Studies, is not present here. Despite the spread of ANT through the social sciences, Kirstie Ball's 'Elements of Surveillance', appears to be the first detailed consideration of the implications of this revisioning of sociology for Surveillance Studies (Ball, 2002). This project attempts to tear away sociology from the legacy of Durkheim to argue that society is always what results from the complex iterations between human, inhuman and nonhuman (actornetworks or collectives) rather than being a given thing or a pre-condition, or indeed exclusively 'human'. It actually has much in common which the arguments put forward by Lianos here and elsewhere, although there appear to be some subtle points of disagreement. We would strongly encourage the kind of empirical work demanded by Lianos and many of the other authors in this issue, based on serious reconsiderations of 'the social'.

We also have no contributions which return to the figure of the Panopticon itself, and consider it anew, either sans or contra Foucault. This perhaps reflects the readership and reach of Surveillance \& Society itself, which despite the progress mentioned earlier, still has not reached all corners of the academic world. Despite some efforts in this area, particularly in our Calls for Papers for this issue, history and architectural theory remain as yet unrepresented. Foucault indeed, despite his association with the revival of interest in the Panopticon and what it represents, was not the only analyst to attempt such a reinterpretation. Perhaps a future issue on the Architecture of Surveillance might be in order. For now though, such we are left to consider the legacy of Foucault... 


\section{References}

Ball, K. (2002) Elements of surveillance: a new framework and future directions. Information, Communication and Society, 5(4): 573-590.

Ball, K. and F, Webster (eds.) (2003) The Intensification of Surveillance: Crime, Terrorism and Warfare in the Information Age. London: Pluto Press.

Deleuze, G. (1990) Post-scriptum sur les sociétés de contrôle. L'autre journal 1; trans M. Joughin (1992) Postscript on the societies of control. October 59: 3-7.

Deleuze, G. and F. Guattari (1980) Capitalisme et schizophrenie tome 2: Mille plateaux. Paris: Éditions de Minuit; trans. B. Masumi (1987) A Thousand Plateaus: Capitalism and Schizophrenia. Minneapolis: University of Minnesota Press.

Foucault, M. (1984) Foucault, (under the pseudonym Maurice Florence, with F. Ewald). In Dictionnaire des Philosophes. Paris: PUF, Vol. I: 941-944.

Graham, S. and D. Wood (2003) Digitising surveillance: categorisation, space, inequality Critical Social Policy, 23(2): 227-248.

Haggerty, K. and R. Ericson (2000) The surveillant assemblage. British Journal of Sociology, 51(4): 605-622.

Lyon, D. (2001) Surveillance Society: Monitoring Everyday Life. Buckingham: Open University Press.

Lyon, D. (2003) Surveillance after September $11^{\text {th }}$. Cambridge: Polity Press. 